\title{
An Evaluation of the Effectiveness of Labor Market Integration Policies in EU Member States Using PROMETHEE
}

\author{
Anastasia Blouchoutzi, University of Macedonia, Greece \\ iD https://orcid.org/0000-0003-3780-374X \\ Panagiota Digkolou, University of Macedonia, Greece \\ Jason Papathanasiou, University of Macedonia, Greece \\ Christos Nikas, University of Macedonia, Greece
}

\begin{abstract}
From an economic point of view, the rational response towards migration is the labor market integration of immigrants. Within the above framework, several actions have been developed by the European Union member states over the last few years, in an effort to integrate migrants to local communities. This paper evaluates the performance of the European Member States as regards to their labor market integration policies using the Zaragoza indicators for employment. Combining those indicators, the data will be processed with the well-known multi-criteria analysis method PROMETHEE. The model will be constituted by the selected years from 2008 to 2017 as 10 successive scenarios, the 28 EU countries as alternatives, and eight criteria. The paper will end up with ten final rankings of the countries, which will be analyzed in detail.
\end{abstract}

\section{KEYWORDS}

European Union, Integration, Migration, Multi-Criteria Analysis, Outranking, PROMETHEE

\section{INTRODUCTION}

Between 1750 and 1960 Europe used to be the world's prime source of migration. Since 1960 though, most of the EU member states have transitioned from countries of emigration to destination countries of immigrants (Munz, 2007). Postcolonial migration was the first migrant wave towards Europe. Labor migration followed, directed mainly to the North-Western European countries, the economies of which were rapidly growing. The end of the Cold War triggered large numbers of asylum seekers and refugees towards the traditional migrant destinations but also the Southern European countries. Several elements distinguished the immigration experiences of the European member states such as their geographical location, their socio-economic development and their historical background (Doomernik \& Bruquetas-Callejo, 2016). 
Social inclusion is one of the key priorities of the Europe 2020 strategy (European Commission, 2010). In this framework, a comprehensive approach towards the implementation of an effective immigrants' labor market integration in the European Union is considered crucial. The targets of the Europe 2020 strategy include $75 \%$ of people aged 20-64 to be in work and at least 20 million fewer people to be in or at risk of poverty and social exclusion. However, there is still an employment gap among EU citizens and non-EU citizens which was estimated in 14.80 percentage points for 2017 (Eurostat, 2018). Moreover, the unemployment rate of immigrants in the EU28 in 2018 is estimated at $15.2 \%$ contrary to the $7.3 \%$ of the EU citizens.

The European Union has adopted the EU Action Plan on the Integration of Third-Country Nationals which specifically refers to the importance of successful labor market integration: "timely and full labor market integration can also help to meet the growing needs for specific skills in the EU as well as to enhance the sustainability of the welfare systems against the background of an aging population and workforce" (European Commission, 2016, par. 4.1.3). However, 26.412.000 immigrants out of the 322.609 .000 , which is the estimated population from 15 to 74 years old of non-EU nationals in the EU-28 in 2018, are unemployed. Furthermore, the migration crisis that followed the Syrian civil war has pushed new migration flows towards the European Union since 2014 through the Mediterranean Sea and land routes and particularly through Spain, Italy, Greece, Cyprus, and Malta. The arrivals are estimated according to UNHCR data in 1.958.126 immigrants, refugees, and asylum seekers. These migration inflows though happened after the Eurozone debt crisis had affected deeply the European labor markets (Lane, 2012). The unemployment rate in the EU-28 in 2013 reached 12,4\% for EU nationals and 22,3\% for immigrants while in some member states like Greece, it amounted to $27,5 \%$. As a result, the field of immigrants' integration in the European societies and specifically the perceptions over this new migrant influx became polarizing.

The purpose of this paper is to provide an evaluation on the effectiveness of the labor market integration policies using the PROMETHEE method, which is a multi-criteria decision analysis method, comparing the gaps between the native and the immigrant population in the Zaragoza indicators for employment, as well as the immigrants' employment indicators among the EU 28 member states. For the purpose of this paper, the use of the word "immigrants" receives its EU context as third-country nationals, establishing their usual residence in the territory of a Member State for different purposes, including humanitarian ones. Specifically, the criterion of citizenship is used to distinguish between immigrants and natives in each member state of the EU-28. The rest of the paper is divided in seven sections. First, a short overview of the importance of integration, the challenges and the appropriate policies to face the challenges of the integration process are presented. Next, the indicators for measuring the integration outcomes are described. A brief introduction into the PROMETHEE method and our case study follows. The results and their sensitivity are analyzed in the last sections and the conclusion wraps up the analysis.

\section{THE INTEGRATION PROCESS}

Integration is a multifaceted three-way process among immigrants, their host countries and the countries of their origin that involves social, political, cultural and economic aspects of life (GarcesMascarenas \& Penninx, 2016). The successful labor market integration of immigrants in their host country is the optimum response towards immigration. After all, labor mobility favors an optimal allocation of resources and leads to higher and more qualitative output and welfare (Zimmermann, 2016). The impact of immigration on the host country's labor market depends on several policies that affect the slope of the labor demand and supply curve. Nevertheless, apart from the policies, it is also the characteristics of the immigrant population and their similarities and differences with the natives that could alter the outcome of immigration on the labor market of the host country (Jean et al., 2010). Labor market integration affects all kinds of immigrants. Employment is essential for them because it increases their self-sufficiency and their socio-economic participation, their standard 
of living, their interactions with the natives and the overall outcome of their inclusion in the host society (OECD, 2018).

The host countries of immigrants have to deal with several challenges in their efforts to implement and succeed in their integration policies. Economic, educational, social and structural barriers complicate and delay the integration process. Indicatively, the housing shortages, the low labor demand, the poor funding and the lack of incentives for employers to hire new immigrant employees are some of the most common economic challenges in the field of integration. The knowledge of the language of the host country, the low skills levels of the immigrants or the lack of the appropriate documentation to recognize their skills is usually referred as educational difficulties in immigrants' labor market integration. Discrimination, racism, lack of social networks and inadequate living conditions constitute the social barriers that have to be dealt with, while from a structural point of view, the vague rules of participation in the labor market along with the lack of coordination among the authorities and the differences in the social security benefits among the EU member states complicate further the sensitive issue of immigrants' integration.

Towards addressing the aforementioned barriers and proceeding with their integration policies, EU Member States have adopted three kinds of approaches (European Migration Network, 2019): the mainstream approach, the individualized approach and the hybrid one. In such a framework, economic policy measures such as the social clauses in the public procurement, the temporary agency employment, the promotion of entrepreneurship and the job matching have been identified to enhance the labor market integration outcomes. Educational approaches like language learning, the qualification programs, the vocational education, the bridging courses, and the ethics education have been proposed to ease the educational difficulties of the new immigrant employees. Additionally, anti-discrimination practices, the mapping of immigrants' skills, access to social services and the career's orientation are social policy initiatives that could ameliorate the integration process. Last but not least, structural reforms that could reduce the time to ensure legal status and clarify the legal rights to employment are necessary steps to achieve the intended labor market integration outcomes.

\section{Zaragoza Indicators for Integration}

EU integration indicators are useful towards understanding the national contexts of EU Member States' labor market integration policies and make it easier to compare and contrast them as well as explain their differences. An effective labor market integration entails the convergence between immigrants' and natives' indicators.

The Zaragoza Declaration was adopted in April 2010 and approved at the Justice and Home Affairs Council on 3-4 June 2010. In the general idea of the Zaragoza Declaration, there is an effort to promote the development of strategies for progress and social cohesion in the European member states. The implementation of such strategies in the short and in the long term is a necessary step towards this direction, which creates a transversal and inclusive approach to integration.

As it is presented in Table 1, there are five areas of interest an integration policy focuses on, which are necessary towards strengthening the social and economic cohesion of a country. According to the Zaragoza Declaration, the most appropriate indicators with regard to the employment priority area and as such labor market integration of immigrants in their destination country are the employment rate, the unemployment rate, the activity rate as well as the self-employment and over-qualification indicators.

The employment rate is the percentage of employed people compared to the working-age population. It is the most important indicator to monitor the EU 2020 strategy employment target. The employed people include the population who had any work for profit or had a job even if they were absent from it. Although this paper does not refer to gender differences but rather the gap between the native and the immigrant population, it should be mentioned that according to Eurostat (2019) there is also a gender gap between the employment rates of men and women in almost all the EU member states. The largest difference between the employment rate of the native and the immigrant 
Table 1. List of Zaragoza indicators

\begin{tabular}{|l|l|l|l|l|}
\hline \multicolumn{1}{|c|}{ Employment } & \multicolumn{1}{|c|}{ Education } & \multicolumn{1}{c|}{ Social Inclusion } & \multicolumn{1}{c|}{ Active Citizenship } & \multicolumn{1}{c|}{ Welcoming Society } \\
\hline Employment rate & $\begin{array}{l}\text { Highest educational } \\
\text { attainment }\end{array}$ & $\begin{array}{l}\text { At-risk-of-poverty } \\
\text { and social } \\
\text { exclusion) }\end{array}$ & Naturalization rate & $\begin{array}{l}\text { Perceived experience of } \\
\text { discrimination (survey) }\end{array}$ \\
\hline Unemployment rate & Tertiary attainment & Income & $\begin{array}{l}\text { Share of long-term } \\
\text { residence }\end{array}$ & $\begin{array}{l}\text { Trust in public } \\
\text { institutions (survey) }\end{array}$ \\
\hline Activity rate & Early school leaving & $\begin{array}{l}\text { Self-reported health } \\
\text { status (controlling } \\
\text { for age) }\end{array}$ & $\begin{array}{l}\text { Share of elected } \\
\text { representatives } \\
\text { (research) }\end{array}$ & $\begin{array}{l}\text { Sense of belonging } \\
\text { (survey) }\end{array}$ \\
\hline Over-qualification & $\begin{array}{l}\text { Language skills of } \\
\text { (PISA) } \\
\text { non-native speakers } \\
\text { (LFS module) }\end{array}$ & Property ownership & $\begin{array}{l}\text { Voter turnout } \\
\text { (research) }\end{array}$ & \\
\hline
\end{tabular}

Source: (Council of the European Union, 2010).

population in 2018 was found in Greece, where the gaps in the labor market indicators between the natives and the immigrants aggravated after the debt crisis.

The unemployment rate refers to the percentage of the labor force that is unemployed during the reference year. The differences between the unemployment rate of the native-born population and the third-country nationals in the EU were relatively small before the global financial crisis, but the gap widened following the economic shock. The lowest unemployment rates with regard to third-country nationals in 2018 were recorded in Czechia (Czech Republic), in Malta, and in the UK, while Greece had the highest, followed by Spain, Sweden, France, and Finland.

The activity rate is an indication of the economically active people compared to the total population. According to Eurostat (2019), between 2008 and 2017, third-country nationals presented lower activity rates than their EU-born peers, but in 2019 this trend seems to change. Netherlands, Latvia, Germany, Denmark, and France belong to the countries with the largest gaps in the activity rates between natives and immigrants, while there are also countries like Slovakia, Czechia, Romania and Greece that had higher activity rates for the foreign-born population than for natives.

The self-employment rate includes the sole or joint owners of the unincorporated enterprises, the unpaid family workers, the outworkers who work outside their usual workplace and workers engaged in production done entirely for their own capital formation. The share of self-employed native-born people in the EU-28 has declined between 2008 and 2018. For the foreign-born population although an increase in self-employment has been observed until 2016 when it also turned downwards.

Over-qualification refers to the situation in which a person has tertiary education and works in low or medium-skilled jobs. The over-qualification rate is usually high among the immigrants and there are regions where the lowest level of migrants' over-qualification surpasses the highest level of the natives' over-qualification leading to immigrants' lower labor productivity and worsening the region's economic development (OECD, 2018).

\section{THE PROMETHEE METHOD}

The multi-criteria analysis method PROMETHEE is one of the methods that belong to the outranking family, like the ELECTREE method. Its acronym is formed by the words Preference Ranking Organization METHod for Enriched Evaluation. The decision maker, using PROMETHEE, will end up with a final ranking of the selected alternatives, which will be based on the computation of 
preference degrees, and he/she will have a single choice or a choice over alternatives as to the best solution of the set group of alternatives and their preference degrees.

In 1982, Jean-Pierre Brands developed the PROMETHEE I (partial ranking) and PROMETHEE II (global ranking). A few years later, in 1995, Jean-Pierre Brands and Bertrand Mareschal developed PROMETHEE III and PROMETHEE VI, introducing a parallel presentation of the GAIA module, a visual interactive tool that offers a graphical presentation of each model and its results. There are also other additional extensions of PROMETHEE that have been developed over the years, see for example the publications of Brans and Mareschal (1994, 2005). Except for those extensions, there are many publications, which use PROMETHEE in order to process a problem (Brans et al., 1986; Vicke and Brans, 1985; D'Avignon and Mareschal, 1989; Briggs et al., 1990; Behzadian et al., 2010). A report from June of 2018 by Mareschal states that the total number of PROMETHEE's references are1827 papers (Mareschal, 2018). Their application areas are among otherslenvironment management, services and public applications, industrial applications, energy and water management, economics and transportation problems.

The procedure of the PROMETHEE method consists of several steps that calculate the final ranking of the selected alternatives. Firstly, the decision maker will construct the table of the decision matrix, integrating all the information about the alternatives, criteria, preference parameters and weights. Then he/she proceeds with the calculation of the differences between the actions' evaluations for each criterion, and the pairwise comparison matrix for each criterion is constructed. Subsequently, the method calculates the unicriterion net flows, where the methodology measures which action is more preferred over all the other actions with positive, negative and net flows, where the positive and negative flows have respectively values between 0 and 1 , and -1 and 0 , and they express how an action is preferred or not over all other action on a specific criterion. While, in unicriterion net flows, the values are between -1 and 1 , and they are calculated by subtracting the negative flows from the positive flows. Afterward, it calculates the weighted unicriterion flows, and finally, the global preference net flows. In the end, the resultis the ranking of the actions according to PROMETHEE I and II. (Brans, 1982; Brans \& Mareschal 1994; 2005)

The decision maker can use qualitative and quantitative criteria. Furthermore, the PROMETHEE method requires as inputs the weights of the selected criteria and the preference function's type. For the latter, the decision maker has to choose between Usual, U-shape, V-shape, Level, Linear and Gaussian, and depending on the type he/she chooses, the appropriate thresholds must be selected. For instance, the Linear function, which will be used in the following case study, requires an indifference threshold $q$ and a preference threshold $\mathrm{p}$. Specifically, when the difference between a criterion's evaluations is less than the selected threshold of indifference q, then there is not perceived a discrepancy between these two actions for the preferences of the decision-maker. In the opposite case, when the difference is higher than the preference threshold p, then the preference is strong (Brans \& Mareschal, 2005).

\section{CASE STUDY}

For the purpose of this paper, the authors make use of the aforementioned indicators for the decade between 2008 and 2017 except the over-qualification rate for which there are no longitudinal data available. Specifically, statistical data available from the Eurostat database have been used for the non-EU population in each member state of the EU-28. Moreover, the gaps in each indicator between the native population and the non-EU population have been included in the analysis so as the ultimate target of immigrants' labor market integration along with an effective social inclusion to be examined.

The Visual PROMETHEE, a freely available software, will be used in order to process the selected data. The model consists of the $28 \mathrm{EU}$ countries as alternatives, and there are eight criteria:

1. Activity rates

2. Employment rates 
Table 2. PROMETHEE Preferences

\begin{tabular}{|c|l|l|l|l|l|l|l|l|}
\hline \multirow{2}{*}{ Preferences } & \multicolumn{9}{|c|}{2008 to 2017 } \\
\cline { 2 - 10 } & $\begin{array}{c}\text { Activity } \\
\text { rates }\end{array}$ & $\begin{array}{c}\text { Employ- } \\
\text { ment } \\
\text { rates }\end{array}$ & $\begin{array}{c}\text { Self- } \\
\text { employ- } \\
\text { ment }\end{array}$ & $\begin{array}{c}\text { Unemploy- } \\
\text { ment rates }\end{array}$ & $\begin{array}{c}\text { GAP_Activity } \\
\text { rates }\end{array}$ & $\begin{array}{c}\text { GAP_Employ- } \\
\text { ment rates }\end{array}$ & $\begin{array}{c}\text { GAP_Self- } \\
\text { employ- } \\
\text { ment }\end{array}$ & $\begin{array}{c}\text { GAP_Une- } \\
\text { mployment } \\
\text { rates }\end{array}$ \\
\hline min/max & $\max$ & $\max$ & $\max$ & $\min$ & $\min$ & min & min & min \\
\hline Weight & 0,12 & 0,12 & 0,12 & 0,12 & 0,13 & 0,13 & 0,13 & 0,13 \\
\hline Preferences function & Linear & Linear & Linear & Linear & Linear & Linear & Linear & Linear \\
\hline thresholds & absolute & absolute & absolute & absolute & absolute & absolute & absolute & absolute \\
\hline Q: Indifference & 3 & 3 & 5000 & 3 & 3 & 3 & 5000 & 3 \\
\hline P: Preference & 10 & 10 & 10000 & 10 & 10 & 10 & 10000 & 10 \\
\hline
\end{tabular}

3. Self-employment

4. Unemployment rates

5. The gap in activity rates

6. The gap in employment rates

7. The gap in self-employment

8. The gap in unemployment rates

At the following table, there is all the selected information for the model that has been constructed for the case study.

The first three criteria need to be maximized, while all the other criteria need to be minimized. Especially for the gaps, they need to be minimized in order to minimize the difference in each indicator between the locals and the immigrants. All the criteria are quantitative. The weights of all the criteria are almost equal because there is no question of preference among the criteria. The type of the function than it has been chosen is linear, thus an indifference threshold $\mathrm{Q}$ and a preference threshold $\mathrm{P}$ for each criterion has been chosen according to the values of the data. In the next table, there are ten rankings of the 28 EU countries for the selected years.

\section{Results Analysis}

Starting the analysis with the Mediterranean countries, it should be mentioned that the model of migration in Southern Europe was mainly characterized by labor and family migration, illegality and frequent amnesties. Italy was the first Mediterranean country to adopt an integration policy in the late nineties followed by Spain, Greece, and Portugal in the early 2000s in which a labor-oriented approach and an economic conception of migration were obvious contrary to the North-Western humanitarian oriented policies (Doomernik \& Bruquetas-Callejo, 2016). This approach upgrades the importance of the labor market integration for effective social inclusion of immigrants.

It can easily be concluded in Table 2 that Greece's position in the ranking has worsened after the economic crisis the country experienced. Greece used to achieve the first place during 2009 and 2010 in the EU-28 labor market integration indicators' ranking portraying effectiveness in narrowing the gaps between the immigrant and the native population in its labor market. At the peak of the crisis, in 2013 though, Greece fell in the 17th position. From 2008 to 2015, the country's GDP dropped by $23 \%$ and the unemployment rate reached a peak of $27.5 \%$. The number of immigrants working in manufacturing and households dropped by $50 \%$. The numbers of those working in commerce, agriculture, and the hospitality and food businesses had less change and the greater decline happened in the number of the construction workers which dropped dramatically from 110.500 to 24.500 (-78\%!). 
Table 3. PROMETHEE results

\begin{tabular}{|c|c|c|c|c|c|c|c|c|c|}
\hline 2008 & 2009 & 2010 & 2011 & 2012 & 2013 & 2014 & 2015 & 2016 & 2017 \\
\hline Hungary & Greece & Greece & Cyprus & Malta & Malta & Cyprus & Slovakia & Malta & Malta \\
\hline Estonia & Portugal & Cyprus & Malta & Cyprus & Czechia & Hungary & Czechia & Slovenia & Czechia \\
\hline Lithuania & Estonia & Portugal & Czechia & Czechia & Cyprus & Lithuania & Cyprus & Estonia & Estonia \\
\hline Portugal & Cyprus & Czechia & Estonia & Lithuania & Lithuania & Czechia & Malta & Italy & Romania \\
\hline Greece & Czechia & Malta & Slovenia & Estonia & Estonia & Malta & Lithuania & Lithuania & Slovenia \\
\hline Cyprus & Hungary & Estonia & Portugal & Romania & Luxembourg & Estonia & Slovenia & Portugal & Portugal \\
\hline Czechia & Poland & Italy & Poland & Slovenia & Hungary & Latvia & Hungary & Czechia & Poland \\
\hline Latvia & Italy & Spain & Italy & Poland & Slovenia & Italy & Estonia & Latvia & Latvia \\
\hline Italy & Malta & Lithuania & Greece & Italy & Portugal & Poland & Latvia & Cyprus & Lithuania \\
\hline Spain & Romania & Romania & Spain & Slovakia & Italy & Portugal & Greece & Spain & Slovakia \\
\hline Ireland & Latvia & Luxembourg & Latvia & Latvia & Latvia & Greece & Spain & Greece & Italy \\
\hline Slovenia & Spain & Slovenia & Slovakia & Luxembourg & Spain & Spain & Portugal & Slovakia & Cyprus \\
\hline Slovakia & Slovakia & Latvia & Romania & Portugal & Romania & Luxembourg & Luxembourg & Denmark & Greece \\
\hline Poland & Luxembourg & Poland & Luxembourg & Bulgaria & Slovakia & Romania & Romania & Ireland & Spain \\
\hline Romania & Ireland & Slovakia & Bulgaria & Hungary & Poland & Slovakia & Italy & Hungary & Luxembourg \\
\hline Malta & $\begin{array}{l}\text { United } \\
\text { Kingdom }\end{array}$ & $\begin{array}{l}\text { United } \\
\text { Kingdom }\end{array}$ & Lithuania & Spain & Germany & Slovenia & Bulgaria & Luxembourg & Ireland \\
\hline $\begin{array}{l}\text { United } \\
\text { Kingdom }\end{array}$ & Denmark & Ireland & $\begin{array}{l}\text { United } \\
\text { Kingdom }\end{array}$ & Greece & Greece & $\begin{array}{l}\text { United } \\
\text { Kingdom }\end{array}$ & Poland & Poland & Hungary \\
\hline Bulgaria & Lithuania & Austria & Hungary & Austria & $\begin{array}{l}\text { United } \\
\text { Kingdom }\end{array}$ & Bulgaria & Ireland & Romania & Denmark \\
\hline Austria & Austria & Hungary & Ireland & $\begin{array}{l}\text { United } \\
\text { Kingdom }\end{array}$ & Ireland & Ireland & Austria & $\begin{array}{l}\text { United } \\
\text { Kingdom }\end{array}$ & $\begin{array}{l}\text { United } \\
\text { Kingdom }\end{array}$ \\
\hline Croatia & Slovenia & Denmark & Austria & Ireland & Denmark & Denmark & Denmark & Austria & Austria \\
\hline Denmark & Finland & Netherlands & Denmark & Germany & Austria & Austria & Sweden & Sweden & Sweden \\
\hline Finland & Germany & France & Netherlands & Denmark & Finland & Germany & $\begin{array}{l}\text { United } \\
\text { Kingdom }\end{array}$ & Bulgaria & Germany \\
\hline France & France & Finland & France & Netherlands & Bulgaria & Sweden & Germany & Germany & Bulgaria \\
\hline Luxembourg & Netherlands & Germany & Finland & Finland & France & France & Netherlands & France & France \\
\hline Sweden & Sweden & Sweden & Sweden & France & Sweden & Finland & Belgium & Netherlands & Finland \\
\hline Germany & Bulgaria & Bulgaria & Germany & Sweden & Netherlands & Netherlands & Finland & Belgium & Netherlands \\
\hline Netherlands & Belgium & Belgium & Croatia & Belgium & Croatia & Belgium & France & Finland & Belgium \\
\hline
\end{tabular}

Most male immigrants used to concentrate on the construction sector in Greece and their households were destabilized by the crisis, which forced them to change the sector of employment. Albanian immigrants for example, who consist more than half of the immigrant population in Greece, since their first entrance and up to the crisis had improved their employment status. They used to receive higher salaries, they had increased their savings and their remittances to Albania and they used to consider staying in Greece permanently (Nikas \& Aspasios, 2011). Nevertheless, the crisis increased the inter-sector mobility of Albanian employees, affected the transfers of remittances to Albania and provoked thoughts for repatriation (Aspasios et al., 2014).

Italy, Spain, and Portugal, at a point, also increased their demand for labor, especially in lowskilled sectors that natives rejected and saw the informal sector of their economies expanding. Their places in the ranking are above average, having some backs and forths during the decade examined, due probably to the economic problems they faced. In fact, a typical example of immigrants' labor market integration in Italy is that the immigrants' share in the country's total employment exceeds their 
share in the country's total population (Bontenbal \& Lillie, 2019). With regard to Spain, immigration policies are open and committed to integration following the public perception that immigration has been positive for economic growth (Arango, 2013).

The Mediterranean islands of Cyprus and Malta keep some of the top places in the ranking. Cyprus though, aggravated its position after 2016, probably due to the high number of asylum seekers and beneficiaries of international protection the island received after the outburst of the migration crisis. As far as the Visegrad countries are concerned, Czechia has increased its demand for foreign labor since 2013 and has shifted its integration policy towards the civic model since 2006 (Drbohlav \& Janurová, 2019). By applying smart, active and systematic migration policies, Czechia is a pioneer in Central Europe. Hungary and Poland are less exposed to immigration inflows, but they do not seem to excel in their integration policies. Slovakia, which also adopted a negative stance towards the relocation of refugees based on the system of quotas along with the other Visegrad countries, has a small number of immigrants compared to its total population and most of them are EU-born. However, Slovakia's place in the ranking is an average one.

The Baltic countries receive a satisfying score even though they have strict and conservative policies to protect their national labor markets. It should be mentioned that the net migration rate is positive only in Estonia, while Latvia and Lithuania are emigration countries and the majority of the immigrants in these countries come from the CIS countries with which they share a common history. As a result, the difficulties of integration are reasoned.

The Nordic countries, which are traditional destinations for immigrants and have implemented various good integration practices, present adverse integration outcomes. Hence, the differences in the employment indicators between the foreign population and the natives remain wide, revealing that apart from the policies, there are also several other elements that affect the effectiveness of immigrants' integration.

France and Germany, two of the oldest European immigrant destinations with the longest integration strategies, have not been able to narrow the gaps between the native and the immigrant population and succeed in the desired target of immigrants' social inclusion either. Netherlands' vision on integration puts the responsibility of integration on the immigrants, but the outcomes according to the ranking do not seem to be rewarding either. When it comes to the UK, where bottom-up initiatives are encouraged in the integration process and to Austria, there is also a below-average consistent score between 2008 and 2017.

Last but not least, Romania seems to achieve higher scores than Bulgaria and Croatia which receive the lowest scores among the EU-28. The only country that competes with Croatia for the last position of the EU-28 labor market integration ranking is Belgium. This is probably attributable to the structural characteristics of the Belgian labor market. There are no longitudinal data available for the over-qualification rate as it was mentioned above. However, it is expected that the results would be further enforced by the use of this extra indicator.

\section{Sensitivity Analysis}

A sensitivity analysis of the weights is always an interesting and useful tool, and in this way, the decision maker can examine how robust is the given solution. Thus, if the intervals of all the criteria are particularly limited, then the given solution is quite sensitive to change. On the other hand, when the intervals are wide, the solution is characterized by robustness. In the case that the given solution is too sensitive to small changes, the decision maker could consider the selected model and he/she can reconstruct it in a more robust way, so the following given final ranking will be more stable.

In Table 4, there all the intervals for the eight criteria for the ten selected years, from 2008 to 2017. It is clear that the limits above the intervals are too strict, and the given solution is not characterized by robustness. This may happen due to the fairly close values of the data entered into the model. In any case, the sensitivity analysis should be taken into account for the flexibility of all the final rankings. For the purpose of this paper, the sensitivity of the results is to be expected, but it does not play a 
Table 4. Sensitivity analysis

\begin{tabular}{|c|c|c|c|c|c|c|c|c|c|c|}
\hline Sensitivity analysis & 2008 & 2009 & 2010 & 2011 & 2012 & 2013 & 2014 & 2015 & 2016 & 2017 \\
\hline Activity Rates & $\begin{array}{l}{[11,33 \%,} \\
13,33 \%]\end{array}$ & $\begin{array}{l}{[11,35 \%} \\
12,41 \%]\end{array}$ & $\begin{array}{l}{[11,87 \%,} \\
12,28 \%]\end{array}$ & $\begin{array}{l}{[11,30 \%,} \\
12,90 \%]\end{array}$ & $\begin{array}{l}{[11,96 \%,} \\
12,26 \%]\end{array}$ & $\begin{array}{c}{[10,91 \%,} \\
12,75 \%]\end{array}$ & $\begin{array}{c}{[10,28 \%,} \\
12,78 \%]\end{array}$ & $\begin{array}{c}{[7,13} \\
15,27 \%]\end{array}$ & $\begin{array}{c}{[11,81 \%,} \\
12,82 \%]\end{array}$ & $\begin{array}{l}{[11,64 \%,} \\
13,93 \%]\end{array}$ \\
\hline $\begin{array}{l}\text { Employ-ment } \\
\text { rates }\end{array}$ & $\begin{array}{l}{[10,52 \%,} \\
13,04 \%]\end{array}$ & $\begin{array}{l}{[11,44 \%} \\
12,89 \%]\end{array}$ & $\begin{array}{l}{[11,70 \%,} \\
12,14 \%]\end{array}$ & $\begin{array}{l}{[10,92 \%,} \\
12,68 \%]\end{array}$ & $\begin{array}{l}{[11,54 \%,} \\
12,04 \%]\end{array}$ & $\begin{array}{c}{[11,01 \%,} \\
13,07 \%]\end{array}$ & $\begin{array}{c}{[11,30 \%,} \\
12,73 \%]\end{array}$ & $\begin{array}{c}{[10,20 \%,} \\
14,80 \%]\end{array}$ & $\begin{array}{c}{[11,82 \%,} \\
12,07 \%]\end{array}$ & $\begin{array}{l}{[11,81 \%,} \\
13,84 \%]\end{array}$ \\
\hline Self-employment & $\begin{array}{l}{[11,39 \%,} \\
12,32 \%]\end{array}$ & $\begin{array}{l}{[10,45 \%} \\
12,09 \%]\end{array}$ & $\begin{array}{l}{[11,10 \%,} \\
12,59 \%]\end{array}$ & $\begin{array}{l}{[11,75 \%,} \\
12,17 \%]\end{array}$ & $\begin{array}{l}{[11,97 \%,} \\
12,32 \%]\end{array}$ & $\begin{array}{c}{[11,55 \%,} \\
12,79 \%]\end{array}$ & $\begin{array}{c}{[11,77 \%,} \\
12,64 \%]\end{array}$ & $\begin{array}{c}{[11,49 \%,} \\
13,34 \%]\end{array}$ & $\begin{array}{c}{[11,45 \%,} \\
12,45 \%]\end{array}$ & $\begin{array}{l}{[11,75 \%,} \\
12,23 \%]\end{array}$ \\
\hline $\begin{array}{l}\text { Unemploy-ment } \\
\text { rates }\end{array}$ & $\begin{array}{l}{[11,36 \%,} \\
13,81 \%]\end{array}$ & $\begin{array}{l}{[11,62 \%} \\
12,39 \%]\end{array}$ & $\begin{array}{l}{[11,86 \%,} \\
12,07 \%]\end{array}$ & $\begin{array}{l}{[11,50 \%,} \\
12,38 \%]\end{array}$ & $\begin{array}{l}{[11,51 \%,} \\
12,08 \%]\end{array}$ & $\begin{array}{l}{[11,40 \%,} \\
12,80 \%]\end{array}$ & $\begin{array}{l}{[11,27 \%,} \\
13,20 \%]\end{array}$ & $\begin{array}{r}{[10,37 \%,} \\
13,29 \%]\end{array}$ & $\begin{array}{l}{[11,96 \%,} \\
12,16 \%]\end{array}$ & $\begin{array}{l}{[10,99 \%,} \\
12,40 \%]\end{array}$ \\
\hline $\begin{array}{c}\text { GAP_Activity } \\
\text { Rates }\end{array}$ & $\begin{array}{l}{[12,19 \%,} \\
15,04 \%]\end{array}$ & $\begin{array}{l}{[11,71 \%} \\
13,33 \%]\end{array}$ & $\begin{array}{l}{[11,19 \%,} \\
13,07 \%]\end{array}$ & $\begin{array}{l}{[12,17 \%,} \\
13,43 \%]\end{array}$ & $\begin{array}{l}{[12,62 \%,} \\
13,45 \%]\end{array}$ & $\begin{array}{l}{[12,11 \%,} \\
13,35 \%]\end{array}$ & $\begin{array}{l}{[11,74 \%,} \\
14,32 \%]\end{array}$ & $\begin{array}{l}{[12,22 \%,} \\
16,14 \%]\end{array}$ & $\begin{array}{l}{[12,64 \%} \\
13,26 \%]\end{array}$ & $\begin{array}{l}{[11,78 \%,} \\
13,33 \%]\end{array}$ \\
\hline $\begin{array}{c}\text { GAP_Employment } \\
\text { rates }\end{array}$ & $\begin{array}{l}{[12,28 \%,} \\
14,34 \%]\end{array}$ & $\begin{array}{l}{[11,57 \%} \\
14,44 \%]\end{array}$ & $\begin{array}{l}{[12,97 \%,} \\
15,07 \%]\end{array}$ & $\begin{array}{l}{[12,03 \%,} \\
13,34 \%]\end{array}$ & $\begin{array}{l}{[12,87 \%,} \\
13,02 \%]\end{array}$ & $\begin{array}{c}{[11,62 \%,} \\
13,55 \%]\end{array}$ & $\begin{array}{c}{[10,42 \%,} \\
13,69 \%]\end{array}$ & $\begin{array}{c}{[12,23 \%,} \\
14,43 \%]\end{array}$ & $\begin{array}{c}{[12,73 \%} \\
13,08 \%]\end{array}$ & $\begin{array}{l}{[11,70 \%,} \\
13,58 \%]\end{array}$ \\
\hline $\begin{array}{l}\text { GAP_Self- } \\
\text { employment }\end{array}$ & $\begin{array}{l}{[12,65 \%,} \\
13,25 \%]\end{array}$ & $\begin{array}{l}{[12,94 \%} \\
14,06 \%]\end{array}$ & $\begin{array}{l}{[12,04 \%,} \\
13,74 \%]\end{array}$ & $\begin{array}{l}{[12,93 \%,} \\
13,22 \%]\end{array}$ & $\begin{array}{l}{[12,86 \%,} \\
13,09 \%]\end{array}$ & $\begin{array}{c}{[12,76 \%} \\
13,35 \%]\end{array}$ & $\begin{array}{c}{[11,56 \%,} \\
13,90 \%]\end{array}$ & $\begin{array}{c}{[11,77 \%,} \\
13,28 \%]\end{array}$ & $\begin{array}{c}{[12,96 \%} \\
13,16 \%]\end{array}$ & $\begin{array}{l}{[12,85 \%,} \\
13,21 \%]\end{array}$ \\
\hline $\begin{array}{l}\text { GAP }_{-} \\
\text {rates }\end{array}$ & $\begin{array}{l}{[11,76 \%,} \\
13,99 \%]\end{array}$ & $\begin{array}{l}{[12,41 \%} \\
13,19 \%]\end{array}$ & $\begin{array}{l}{[11,18 \%,} \\
13,25 \%]\end{array}$ & $\begin{array}{l}{[12,54 \%,} \\
13,61 \%]\end{array}$ & $\begin{array}{l}{[12,21 \%,} \\
13,29 \%]\end{array}$ & $\begin{array}{l}{[12,01 \%,} \\
14,93 \%]\end{array}$ & $\begin{array}{l}{[12,36 \%,} \\
13,65 \%]\end{array}$ & $\begin{array}{l}{[11,97 \%,} \\
13,52 \%]\end{array}$ & $\begin{array}{c}{[12,04 \%,} \\
13,05 \%]\end{array}$ & $\begin{array}{l}{[10,93 \%,} \\
13,34 \%]\end{array}$ \\
\hline
\end{tabular}

negative role in the given rankings, as the selected model could not be formulated in a different way. Presumably, an interesting idea would be to use different weights, in order to focus more on selected criteria, and then to examine how each ranking and the model's robustness of the solution will react.

\section{CONCLUSION}

In a period of an escalating public debate on the management of migration and the direction as well as the effectiveness of integration policies, this paper uses the multi-criteria decision analysis method PROMETHEE to evaluate the integration outcomes of the 28 member states of the European Union over the decade 2008-2017. The results of the empirical analysis provide with an interesting ranking of the EU-28 integration indicators for employment.

Although the Nordic or some Central European countries seem to implement an innovative labor market integration policy, the outcomes as regards the employment, unemployment, activity and selfemployment indicators of immigrants in these countries as well as the gaps in the aforementioned indicators between the immigrants and the natives seem adverse. On the other hand, the Mediterranean countries, dealing with various economic problems, used to include the immigrant population in their societies quite successfully until the peak of the recession. This positive observation could stimulate a more targeted integration policy that could benefit from the various examples of good practices to enforce its outcomes.

Considering the above, the results of the above model are quite interesting, and some rankings changed in an unexpected way. Of course, the model is represents only a specific point of view in time and space of the selected subject and it can potentially be examined in many other ways. For further examination and future works, a researcher could for example, among other options, combine a variety of other weights and preference functions and even criteria and alternatives in order to study alternative groups of countries with similar characteristics. 


\section{REFERENCES}

Arango, J. (2013). Exceptional in Europe? Spain's experience with Immigration and Integration. Migration Policy Institute.

Aspasios, D., Nikas, C., \& Koutsoupias, N. (2014). The Economic Crisis in Greece and the Implications for the Albanian Immigrants. Data Analysis Bulletin, 15, 42-53.

Behzadian, M., Kazemzadeh, R. B., Albadvi, A., \& Aghdasi, M. (2010). PROMETHEE: A comprehensive literature review on methodologies and applications. European Journal of Operational Research, 200(1), 198-215. doi:10.1016/j.ejor.2009.01.021

Bontenbal, I., \& Lillie, N. (2019). Policy Barriers and Enablers. WP3 Report. Horizon 2020 SIRIUS (770515). University of Jyväskylä. Retrieved May 29, 2019 from https://www.sirius-project.eu/sites/default/files/ attachments/SIRIUS\%20WP3\%20-\%20D3.2_0.pdf

Brans, J., \& Mareschal, B. (2005). PROMETHEE methods. In J. Figueira, S. Greco, \& M. Ehrgott (Eds.), Multiple Criteria Decision Analysis: State of the Art Surveys (pp. 163-186). Springer Science + Business Media, Inc. doi:10.1007/0-387-23081-5_5

Brans, J. P. (1982). Lingenierie de la decision la methode Promethee, Instruments et Perspectives Avenir. Presses del Universitete Lavel, 183-213.

Brans, J. P., \& Mareschal, B. (1994). The PROMETHEE GAIA decision support system for multicriteria investigations. Investigation Operative, 4(2), 107-117.

Brans, J. P., \& Mareschal, B. (1995). The PROMETHEE VI procedure. How to differentiate hard from soft multicriteria problems. Journal of Decision Systems, 4(3), 213-223. doi:10.1080/12460125.1995.10511652

Brans, J. P., Vincke, P., \& Mareschal, B. (1986). How to select and how to rank projects: The PROMETHEE method. European Journal of Operational Research, 24(2), 228-238. doi:10.1016/0377-2217(86)90044-5

Briggs, T., Kunsch, P. L., \& Mareschal, B. (1990). Nuclear waste management: An application of the multicriteria PROMETHEE methods. European Journal of Operational Research, 44(1), 1-10. doi:10.1016/03772217(90)90308-X

Council of the European Union. (2010). Declaration of the European Ministerial Conference on Integration. Zaragoza 15-16/4/2010. Retrieved May 29, 2019 from https://ec.europa.eu/migrant-integration/librarydoc/ declaration-of-the-european-ministerial-conference-on-integration-zaragoza-15-16-april-2010

D'Avignon, G., \& Mareschal, B. (1989). An application of the PROMETHEE and GAIA methods. Mathematical and Computer Modelling, 12(10-11), 1393-1400. doi:10.1016/0895-7177(89)90376-2

Doomernik, J., \& Bruquetas-Callejo, M. (2016). María National Immigration and Integration Policies in Europe Since 1973. In B. Garces-Mascarenas \& R. Penninx (Eds.), Integration Processes and Policies in Europe Contexts, Levels and Actors. IMISCOE Research Series. Springer. doi:10.1007/978-3-319-21674-4_4

Drbohlav, D., \& Janurová, K. (2019, June 6). Migration and Integration in Czechia: Policy Advances and the Hand Brake of Populism. Migration Information Source.

Eurocities. (2017). Labour Market Integration of Refugees and Asylum Seekers. Brussels: Eurocities.

Eurofound. (2016). Approaches to the labour market integration of refugees and asylum seekers. Luxembourg: Publications Office of the European Union.

European Commission. (2010). Europe 2020: A strategy for smart, sustainable and inclusive growth Communication from the Commission 2020 final, Brussels 3/3/2010.

European Commission. (2016). Action Plan on the integration of third-country nationals - Communication from the Commission to the European Parliament, the Council, the European Economic and Social Committee and the Committee of the Regions 377 final, Brussels 7/6/2016.

European Commission. (2019). European Web Site on Integration. Migrant Integration Information and Good Practices. Retrieved May 29, 2019 from https://ec.europa.eu/migrant-integration/home 
European Employment Policy Observatory. (2016). Challenges faced by asylum seekers and refugees in successfully integrating into the labour market - Synthesis Report. Publications Office of the European Union.

European Migration Network. (2016). Integration of beneficiaries of international/humanitarian protection into the labour market: policies and good practices - Synthesis Report. European Migration Network.

European Migration Network. (2019). Labour Market Integration of Third-Country Nationals in EU Member States - Synthesis Report. European Migration Network.

Eurostat. (2018). Smart, greener, more inclusive? Indicators to support Europe 2020 strategy. Luxembourg: Publications Office of the European Union.

Eurostat. (2019). Migrant Integration Statistics - labour market indicators. Author.

Garces-Mascarenas, B., \& Penninx, R. (2016). Introduction: Integration as a Three-Way Process Approach? In B. Garces-Mascarenas \& R. Penninx (Eds.), Integration Processes and Policies in Europe Contexts, Levels and Actors. IMISCOE Research Series. Springer. doi:10.1007/978-3-319-21674-4_1

Hooper, K., Desiderio, M. V., \& Salant, B. (2017). Improving the Labour Market Integration of Migrants and Refugees: Empowering Cities Through Better Use of EU Instruments. Migration Policy Institute Europe.

Jean, S. et al.. (2010). Migration and labour market outcomes in OECD countries. OECD Journal: Economic Studies, 2010(1). Advance online publication. doi:10.1787/eco_studies-2010-5kmhf827kws6

Kalantaryan, S. (2016). The Labour-Market Integration of Refugees and Asylum Seekers as a Special Category of Migrants: Evidence and Literature Review. In From Refugees to Workers. Mapping Labour-Market Integration Support Measures for Asylum Seekers and Refugees in EU Member States, Volume II: Literature Review and Country Case Studies (pp. 11-25). Gütersloh: Bertelsmann Stiftung.

Lane, P. R. (2012). The European Sovereign Debt Crisis. The Journal of Economic Perspectives, 26(3), 49-68. doi:10.1257/jep.26.3.49

Mareschal, B. (2018) PROMETHEE-GAIA Statistics. Retrieved June 16, 2018 from http://www.promethee-gaia. net/assets/promethee-stats.pdf

Munz, R. (2007). Migration, Labor Markets and Integration of Migrants: An Overview for Europe. Hamburg Institute of International Economics Policy Paper 3-6.

Nikas, C., \& Aspasios, D. (2011). The changing characteristics and the maturity of Albanian emigration to Greece. Journal of Balkan \& Near Eastern Studies, 13(3), 287-301. doi:10.1080/19448953.2011.593336

OECD. (2018). Working Together for Local Integration of Migrants and Refugees. OECD Publishing.

Vicke, P., \& Brans, J. P. (1985). A preference ranking organization method. The PROMETHEE method for MCDM. Management Science, 31, 641-656.

Zimmermann, F. K. (2017). Refugee and Migrant Labor Market Integration: Europe in Need of a New Policy Agenda. In R. Bauböck \& M. Tripkovic (Eds.), The Integration of Migrants and Refugees: An EUI Forum on Migration, Citizenship and Demography (pp. 88 - 100). Florence: European University Institute, Robert Schuman Centre for Advanced Studies. 
Anastasia Blouchoutzi is a Ph.D. Candidate in the Department of International and European Studies at the University of Macedonia. She is at the final stage of her Ph.D. research that focuses on International Migration. Her research interests include Migration Studies, International Economics, International Studies and Macroeconomics. Papers she has written on these areas have been published in edited journals. She has also participated in peerreviewed conferences. Anastasia has considerable research experience as research assistant in various Greek and EU-funded projects like Erasmust. She holds a BA in International Studies and an MSc in International Economics. She speaks five languages, and she has ten years' experience in project administration and sales positions.

Panagiota Digkoglou received her MSc in Information Systems from the University of Macedonia in Greece, with a great interest in decision support systems, multiple criteria decision making, operations research and analysis and design of information systems. She holds a bachelor degree in Business Administration from the Department of Business Administration at the University of Macedonia. She is a Ph.D. candidate at the University of Macedonia.

Jason Papathanasiou is an Associate Professor at the Department of Business Administration, University of Macedonia, Greece. He holds a PhD in Operational Research and a degree in Physics from the Aristotle University of Thessaloniki. He has worked for a number of years at various institutes and has organized and participated in a number of international scientific conferences and workshops. He has published papers in international scientific peer referred journals like the Environmental Monitoring and Assessment, Regional Studies, European Journal of Operational Research, PNAS, Fuzzy sets and Systems, and has edited or authored a number of books. He has participated and coordinated many research projects in FP6, FP7, Horizon 2020, Erasmus+, Interreg and COST; he was also a member of the TDP Panel of COST. His research interests include Decision Support Systems, Operational Research and Multicriteria Decision Making.

Christos Nikas is a professor at the Department of International and European Studies of the University of Macedonia. Greece. He studied in Greece (B.A.), Belgium (Diploma and Master) and the UK (Ph.D.) He has taught in Greek and British Universities. He has worked as a specialist for the International Organisation for Migration and the European Social and Economic Commission. His published work (5 books and 54 articles) focuses on International Economics, European Economic Integration, Migration and the Greek Economy. 